\title{
Feasibility Demonstration for the Transformation of Excellent Higher Vocational Colleges into Applied Technical Universities
}

\author{
Gou Xue \\ (Business school ,Binzhou Polytechnic, Binzhou256603 ,China ; \\ gouxue001@126.com)
}

\begin{abstract}
In order to construct the modern vocational education system and make the vocational education go through, the government has put forward the idea of constructing the application of the technical university. The application of technology-based universities by local colleges restructuring or by the existing demonstration vocational colleges upgraded two, or both, the debate is more and more intense.This paper refutes the views that Higher Vocational Colleges is not suitable for the transition to the application of technology-based universities, analyzes the advantages of the development of Higher Vocational Colleges, and puts forward the construction for technology of colleges and universities need more scientific and objective standards, the standard design is carried out from the aspects of teachers, experimental training and student quality.
\end{abstract}

Key words: Transformation, applied technology, higher vocational colleges

\section{Who is More Appropriate to Turn into the Applied Technical Universities}

In order to construct the modern vocational education system and make the vocational education go on and on, the government has put forward the idea of constructing the application of the technical university. The application of technology-based universities by local colleges restructuring or by the existing demonstration vocational colleges upgraded two, or both, the debate is more intense. There are some colleges and universities said that the proportion of teachers and students in higher vocational colleges, teachers and education level is relatively low, the academic atmosphere is weak and other issues. The author, as an educator in higher vocational colleges, is to refute the above questions as follows:

(1) The Wide Gap of the Ratio Between Teachers and Students? Educational System and Part-time Teachers Can not be Ignored

With the rapid development of occupation education, occupation colleges have emerged like bamboo shoots after a spring rain, in recent years, occupation colleges continue to expand the scale and increase the number of graduates of the occupation education, the higher education of our country has occupied "half of the country", the total number of occupation colleges students has exceeded the number of undergraduate students, became the largest group of employment of college graduates in China the. Occupation colleges and undergraduate enrollment each year is similar, but higher vocational college teachers of college teachers is only $41.8 \%$, It can't be denied that there was a certain degree of teacher-student ratio gap problem.

Vocational college education system is generally three years, and undergraduate colleges and universities are generally four years, from the school system, the teachers in undergraduate colleges and universities should be more than higher vocational colleges.

In addition, the Ministry of education "several opinions on improving the teaching quality of higher occupation education" (high [2006]16) explicitly proposed "to employ a large number of industry professionals and skilled craftsmen as a part-time teacher at the school, and gradually increase the proportion of part-time teachers, and gradually form a mechanism of practical skills 
curriculum consists of part-time teachers with high skills the level of teaching". Part-time teachers are mostly research master very capable level, or some famous enterprises of first-line managers, they are in the student teaching, finishing the height and bring the student's feeling is not the same, they can get a multiplier effect in teaching. Therefore, a large number of part-time teachers have been hired from the enterprises, effectively alleviate the shortage of teachers.

\section{(2) Low Education? Double Qualified Teachers More Reliable}

Some education experts cited figures that occupation college teachers have the lower titles and educational background than undergraduate college teachers, faced with this question, first is subject to the state control plan, not at the mercy of the school.

At the same time, according to the cultivation of high-quality talents, "the educational philosophy of Higher Vocational Colleges in recent years, the Ministry of education put forward the" Double Teachers "call, to enhance the quality of teachers occupation colleges put forward new demands, simply said," Double Teachers "is the" double certificate "or" double teachers the title of "teacher" teacher + intermediate or above technical positions (or occupation qualification), "double type teacher characteristics and key education of higher vocational teachers, vigorously strengthen the construction of the" double "teachers, has become the common voice of the society and the education sector. The concept of "Double Teachers" in higher vocational colleges, the teachers should not only have a professional, but also to practice, theory and practice of parallel, with particular emphasis on the practice ability and operation ability; only to be able to teach, but also educating people.

(3) Difficulty of Concept Transformation ? It is More Difficult to Change the Concept of Undergraduate Colleges and Universities

Some education experts believe that with the homogeneity positioning of running local universities and training objectives and occupation education, whose transformations are the same, but ignored a very important point, is the concept of transformation. Some colleges and universities and the local industrial structure development, demand is not high, professional advantages and characteristics is not obvious, there are avoided transformation of ideological concerns, that do occupation education is dwarfed by their level of education, which is related to the social reputation of occupation education in our country is not high enough, the attraction is not strong enough. The National Center for education development research, director of High Pavilion Malu said, "there are still some undergraduate colleges and Universities are still at the university development, therefore, is the most die hard concept."

\section{The Advantages of Higher Vocational Colleges}

When we compare the local undergraduate and higher vocational colleges, it is easy to find that many vocational colleges are superior to some local colleges and universities in some aspects.

\subsection{Vocational Colleges Creat Better Workplace Atmosphere}

With the development of education more and more rapidly, it is undeniable that the undergraduate academic atmosphere has become increasingly concentrated, but the cultural soft power is not only the so-called academic atmosphere, vocational (specialist) itself has more workplace atmosphere.

One is the higher vocational employment oriented personnel training, according to the order, some students just entered the school were booked, at the same time, the graduates of Higher Vocational Colleges with practice training and post the opportunity, the graduates of higher vocational colleges has a certain advantage in the post occupation ability reserve. Two is due to forward occupation career education in higher vocational colleges, the employment of graduates in the preparatory work done early, so that students in Higher Vocational Colleges early job psychological preparation, vocational college graduates than ordinary university graduates employment alert period appeared earlier. In this way, higher vocational college graduates in employment psychological preparation also has a certain advantage in the workplace.

\subsection{Higher Vocational Colleges Have Better Practical Training Advantages}

Practice and training conditions are the necessary hardware condition for every higher vocational 
college, and the higher vocational college graduates have more opportunities to practice and practice in school. In addition, the occupation college enterprise cooperation started early, especially some strong technical background, and industry closely, the transformation started earlier in the enthusiasm of university is particularly high, has served as the application oriented university "bellwether", some higher vocational colleges in the setting of professional jobs targeted strong, some higher vocational colleges also has to enterprise "title class", graduates can go directly to the enterprise, therefore, the graduates of higher vocational colleges has a competitive advantage in their own positions in the field.

\subsection{Higher Vocational Graduates Have a More Rational View of Employment}

First of all, the more practical employment concept makes higher vocational college graduates have comparative advantage in employment. Compared with the undergraduates, the concept of employment of graduates in higher vocational colleges is more practical, less employment choice, rational employment, which makes their employment space is more and more widely, the employment level is more abundant. Secondly, hard-working attitude that employment of graduates of higher vocational colleges have certain comparative advantages. Because higher vocational colleges pay attention to the production line operation skill training, the vocational college graduates "beyond" the defects of undergraduates "pure theory", has the characteristics of practice, will be hands-on, and occupation orientation of higher vocational students than undergraduates to be clear, in the employment of the higher vocational students is not as easy to chop and change.

\section{The Standards of Further Building the Application of Technical Colleges and Universities}

Look at the views of some people now believe that local colleges restructuring is more appropriate, this conclusion was drawn in an overall comparison of the. It can not be denied that the overall level of local colleges and universities is higher than the current higher vocational colleges, but the application of technical colleges or universities is not the overall behavior.

In fact, which schools are suitable for the completion of the application of technical colleges and universities, who is not suitable for the right, the need for objective, scientific evaluation. The key to the problem is the need for a unified standard for the application of technical colleges and universities to overcome arbitrary, mechanical, subjective, who is right who does not fit the argument.

\subsection{Standards for Teachers}

At present, no matter what schools, many teachers only use the teaching method of a kind of teaching method, this single teaching mode not only make students feel boring, and the lack of innovative ideas and desires.

Teaching measure applied technology university teachers are qualified, there are three main criteria: first, to encourage students to study independently, protect and further stimulate the imagination and innovation enthusiasm of students; second, to promote the teaching experience, to create a real business scene for students to lay a good foundation for students to adapt to the job; third to promote, between the various courses, and cultivate students' ability of combining theory and practice.

It is necessary for the teachers to master certain theoretical knowledge and practical ability, and to become a "double qualified" teachers with double qualities. Not only the number of teachers required to have the quality of double teachers, while the teacher's practical ability, practical ability, practical teaching, the ability to guide the scene, are the assessment criteria.

At the same time, it is necessary to attach importance to the training of teachers, especially the training of teachers should be diversified development. The training of teachers, continuing education, is not only the double certificate, dual degree, more practice should be combined with scientific research and other aspects of the model, not only by the national and provincial teacher training base to train teachers, teachers should also go to the international and domestic first-class large enterprises and consortia industry training, or attachment, can also go to private enterprises or SMEs part-time, so that teachers know the market needs, industry needs, but also to carry out 
teaching reform.

\subsection{Standards for Experimental Training Conditions}

Practical ability is an important guarantee for the transformation of knowledge into material, and it is a practical skill necessary for senior professionals. For graduates, regardless of the future engaged in teaching, scientific research, or in the production line of technical management work, the strength of hands-on ability, will directly affect the level of energy. The construction of experimental training conditions is the key technology of the practice teaching, is the application of technology of university education reform "core" and "breakthrough", related to the training of personnel adaptability, related to the employment of students, related to the survival and development of Higher Vocational education.

The campus practice teaching base of Applied Technology University should be in accordance with industry groups or application categories focus on the layout and construction, and should not be emphasized in one-to-one correspondence with the set of professional training, to avoid the lack of venues, outdated equipment, simulation of such problem is not enough. To strengthen the construction of campus productive training base, through the cooperation between schools and enterprises, to build qualified and stable conditions of training in and out of school, and give full play to its role in the cultivation of talents. At the same time, it is necessary to build a team with excellent skills and high quality, as well as a set of perfect management rules and regulations.

Training mode of application of technology-based universities must vigorously promote the school enterprise cooperation, pay attention to cultivate students' practical ability, can make full use of the occupation education by Singapore "teaching factory" mode, the school from the manufacturer undertake industrial production project as a graduation design topic, the way manufacturers to provide or borrow in a school equipment a complete and practical factory production workshop, the actual operation of students in teachers and part-time teachers guidance and training, in this mode of teaching, students complete works is the enterprise is the production and sale of products, at the same time, in addition to test whether the quality of clearance products, but also the students' work time cost evaluation of artificial cost etc. Therefore, "teaching factory" is the true meaning of the school enterprise cooperation mode.

\subsection{Standards for the Pertinence and Adaptability of Students' Professional Quality}

The construction of applied technical university should first consider the question of what kind of people should be trained. In today's society, we should pay more attention to the cultivation of students' professional quality and professional ability.

(1) Adaptability

Adaptability is a reflection of the overall quality of a person, and the individual's ideological and moral qualities, knowledge and skills, creative ability and other closely related. A person with strong ability to adapt to the new environment quickly, even in the more difficult circumstances, but also to change the unfavorable factors for the favorable factors, to achieve success in career.

(2)Communication ability

The ability of interpersonal communication is the crystallization of people's practical experience. Therefore, to improve their communication ability, we must boldly participate in various exchange opportunities, develop their own and others in the psychological aspects of compatibility, communication between the honest and the equality of personality and psychological quality.

(3) Expression ability

The expression ability mainly includes the oral expression ability, the written expression ability, the numeral expression ability, the chart expression ability and so on. Should grasp the following points: first to dare to say, this is the premise of good eloquence; secondly, to do something to say (knowledge), which is the basis of practicing good eloquence; again is to be good at conversation, this is the key to good eloquence. One of the basic material writing skills but also a variety of senior specialized talents necessary, but the current university graduates writing skills but poor in general, which is part of the university curriculum and the training mode is not perfect relevant. Therefore, students should seize the time to study the relevant works and models, do more exercises in order to make their own ability to express and improve the ability to express. 
(4)Innovation ability

The ability of innovation and innovation is a kind of resultant force formed by the integration of all kinds of intelligence and ability on the new level. To cultivate the ability of innovation and development, we should pay attention to the accumulation of knowledge and enhance the ability, and pay attention to the cultivation of imagination and divergent thinking.

\section{Conclusion}

In short, whether it is local colleges, higher vocational colleges has the condition, measure on a scale, according to a standard assessment, who is more suitable to decide who will be at a glance, as the main body for the construction of Applied Technology University, will also be more scientific.

The relationship between occupation education and support from all walks of life, to put down the burden from the interests of the game, really need to build a modern occupation education system of the nation, careful thinking, correct understanding or turn the application of technology-based universities problems.

\section{Reference}

[1] Pan Huagui, Deng Jinyan. Reflections on the management of part-time teachers in Higher Vocational Colleges under the new form [J]. Vocational Education Forum, 2012,23 (86-88)

[2] Wu Junmei. The dilemma and solution of the construction of part-time teachers in Higher Vocational Colleges [J]. vocational and technical education, 2013,11: (83-85)

[3] Ma Luting. Construction of the University of technology, China higher education, 2014 (10).

[4] Liu Jiashu. Features of the New Era Connotation Construction in Higher Vocational Colleges of Liaoning [J]. vocational college journal, 2007, (1). 